\title{
Metode Regresi Linier untuk Prediksi KebutuhanEnergi Listrik Jangka Panjang (Studi Kasus Provinsi Lampung)
}

\author{
M. Syafruddin ${ }^{1}$, Lukmanul Hakim ${ }^{2}$, Dikpride Despa ${ }^{3}$ \\ Jurusan Teknik ElektroUniversitas Lampung, Bandar Lampung \\ Jl. Prof. Sumantri Bojonegoro no. 1 lampung 35145 \\ ${ }^{1}$ udinbonkestudents.unila.ac.id \\ ${ }^{2}$ plgsekipdeng.unila.ac.id \\ ${ }^{3}$ despaeeng.unila.ac.id
}

\begin{abstract}
Abstrak - Meningkatnya pembangunan di Provinsi Lampung terutama di sektor perumahanbaik sederhana maupun rumah mewah yang membawa konsekuensi logis berupapeningkatan kebutuhan tenaga listrik. Sebuah studi komprehensif dalam rangkapenyedian tenaga listrik di Lampung menjadi kebutuhan yang mendesakdilakukan untuk membuat rencana operasi sistem tenaga listrik. Salah satu faktoryang sangat menentukan dalam membuat rencana operasi sistem tenaga listriktersebut adalah prediksi beban listrik yang akan ditanggung oleh sistem tenagalistik yang bersangkutan. Penelitian ini bertujuan untuk memprediksi kebutuhan energi listrik di Provinsi Lampung hingga Tahun 2030, diharapkan dapatdijadikan sebagai masukkan dalam melakukan perencanaan pembangunan sistemtenaga listrik. Prediksi kebutuhan energi listrik Lampung dibagi menjadi 4 sektoryaitu : sektor rumah tangga, bisnis, publik, dan industri. Proses perancanganprediksi kebutuhan energi listrik menggunakan 6 variabel dan dibagi menjadi 2 parameter, yaitu: parameter ekonomi (produk domestik regional bruto, jumlahpenduduk, jumlah rumah tangga) dan parameter listrik (rasio elektrifikasi, faktor beban, losses). Dengan menggunakan metode regresi linier untuk memprediksivariabel-variabel di atas, diperoleh hasil prediksi daya listrik tersambung totalpada tahun 2028 sebesar 2.841,78 MVA (rata-rata pertumbuhannya sebesar 2,38 \%), dan konsumsi energi listrik pada tahun 2023 sebesar 5.934,98 Gwh (rata-rata pertumbuhannya sebesar 3,83\%).
\end{abstract}

Kata Kunci —regresi linier, konsumsi energi listrik, Provinsi Lampung.

Abstract The Increasing of property development in Lampung Province, especially in thehousing sector both simple and luxurious brings a logical consequence ofelectricity demand. A comprehensive study for electricity provisioning inLampung become requirement constrain. Electrical load forecasting is one of theimportant factors is power system planning and making. Prediction of electricityconsumption there are for activity that need to be predicted i.e.: households,businesses, public services, and industry. 6 variables include are considered grossregional domestic product, population, number of households, electrification ratio,load factor, losses are considered to be influencing the forecasting proses. Linearregression method was used to predict all variables. The result of total electricitypower connected prediction on 2028 is 2841.78 MVA (growth average at of $2,38 \%$ ). And electricity consumption prediction on 2023 is $5934.98 \mathrm{Gwh}$ (growthaverage at $3,83 \%$ ).

Keywords-linier regression, electricity consumption, Lampung Province.

\section{PENDAHULUAN}

Laju pertumbuhan jumlah kendaraan. Meningkatnya pembangunan yang ada di Provinsi Lampung terutama di sektor perumahan baik sederhana maupun rumah mewah yang membawa konsekuensi logis berupa peningkatan kebutuhan tenaga listrik. Selain itu, kebijakan pemerintah daerah tentang investasi yang menarik minat para investor untuk menanamkan modalnya dan juga memberikan konstribusi dalam peningkatan kebutuhan tenaga listrik.Pada saat ini sistem kelistrikan di Provinsi Lampung masih memerlukan suplai daya listrik dari
Sumatera Selatan (Sistem SumBagSel) meskipun PLN Lampung telah menjadi unit bisnis yang independen. Namun di tahun - tahun yang akan datang suplai dari Sumatera Selatan diharapkan dapat dikurangi. Untuk mewujudkan hal tersebut, sistem kelistrikan Lampung harus mampu mencukupi kebutuhan energi listrik secara mandiri. Jika semua hal ini telah terwujud, konsep interkoneksi antara Provinsi Lampung dengan Sumatera Selatan akan menjadi interchange.Sebuah studi komprehensif jangka panjang dalam rangka penyedian tenaga listrik di Lampung menjadi kebutuhan yang mendesak. Salah satu faktor yang 
sangat menentukan dalam membuat rencana operasi sistem tenaga listrik adalah perkiraan beban listrik yang akan ditanggung oleh sistem tenaga listik yang bersangkutan.

\section{TINJAUAN PUSTAKA}

\section{A. Prediksi}

Prediksi pada dasarnya merupakan dugaan atau prediksi mengenai terjadinya suatu kejadian atau peristiwa di waktu yang akan datang. Prediksi bisa bersifat kualitatif (tidak berbentuk angka) maupun kuantitatif (berbentuk angka). Prediksi kualitatif sulit dilakukan untuk memperoleh hasil yang baik karena variabelnya sangat relatif sifatnya. Prediksi kuantitatif dibagi dua yaitu: prediksi tunggal (point prediction) dan prediksi selang (interval prediction). Prediksi tunggal terdiri dari satu nilai, sedangkan prediksi selang terdiri dari beberapa nilai, berupa suatu selang (interval) yang dibatasi oleh nilai batas bawah (prediksi batas bawah) dan batas atas (prediksi tinggi) [1].

Prediksi berfungsi untuk membuat suatu rencana kebutuhan (demand) yang harus dibuat yang dinyatakan dalam kuantitas (jumlah) sebagai fungsi dari waktu. Prediksi dilakukan dalam jangka panjang (long term). Prediksi yang berkaitan dengan pernyatan (1) what will be demanded, (2) how many, dan (3) when it should be supplied? Prediksi sangat diperlukan dengan melakukan perbandingan antara kebutuhan yang diramalkan dengan yang sebenarnya

\section{B. Metode Prediksi Regresi}

Metode prediksi regresi dibedakan menjadi dua: regesi linier, dan regresi non linier.

1. Regresi linier

Regresi linier merupakan bentuk hubungan di mana variabel bebasX maupun variabel tergantungYsebagaifaktoryangberpangkatsatu.

Regresilinierinidibedakanmenjadi [4]:

a) Regresiliniersederhanadenganbentukfungsi:

$$
\mathrm{Y}=\mathrm{a}+\mathrm{bX}
$$

b) Regresilinierberganda

den g a $n$ bentukfungsi: $\mathrm{Y}=\mathrm{b} 0+\mathrm{b}_{1} \mathrm{X}_{1}+\ldots+\mathrm{b}_{\mathrm{p}} \mathrm{X}_{\mathrm{p}} \ldots$ (2)

Dari kedua fungsi di atas (1dan 2); masing-masing berbentuk garis lurus (linier sederhana)danbidangdatar(linierberganda).

\section{Regresi Non Linier}

Regresinonlinierialahbentukhubunganataufungsidi manavariabelbebasXdanatau variabel tak bebas Y dapat berfungsi sebagai faktor atau variabel dengan pangkat tertentu. Selain itu,variabel bebas Xdan atau variabel tak bebas Ydapat berfungsi sebagai penyebut (fungsi pecahan), maupun variabel $\mathrm{X}$ dan atau variabel $\mathrm{Y}$ dapat berfungsisebagaipangkatfungsieksponen=fungsipe
rpangkatan.Regresi non linier dibedakan menjadi [4]:
a) Regresi Polinomial
b) Regresihiperbola (fungsiresiprokal).
c) Regresi Eksponensial
d) Regresi Logaritmik
e) Regresifungsigeometri.

\section{Jangka Waktu Peramalan}

Prediksi kebutuhan energi listrik dapat dikelompokkan menurut jangka waktunya menjadi tiga kelompok, yaitu [5]:

a) Prediksi jangka panjang

Prediksi jangka panjang merupakan prediksi untuk jangka waktu diatas satu tahun. Dalam prediksi jangka panjang masalah-maslah makro ekonomi (Pendapatan Domestik Regional Bruto atau PDRB) merupakan masalah ekstern perusahaan listrik merupakan faktor utama yang menentukan arah prediksi kebutuhan energi.

b) Prediksi jangka menengah

Prediksi jangka menengah merupakan prediksi untuk jangka waktu dari satu bulan sampai dengan satu tahun. Dalam prediksi beban jangka menengah faktor-faktor manajerial perusahaan merupakan faktor utama yang menentukan. Masalah-masalah manajerial misalnya kemampuan teknis memperluas jaringan distribusi, kemmapuan teknis menyelesaikan proyek pembangkit listrik baru serta juga kemampuan teknis menyelesaikan proyek saluran transmisi.

c) Prediksi jangka pendek

Prediksi jangka pendek adalah prediksi untuk jangka waktu beberapa jam sampai satu minggu $(7 \mathrm{x} 24$ jam $=168 \mathrm{jam})$.

\section{Uji Model}

Untuk menguji model yang akan digunakan apakah ada hubungan dengan parameter yang digunakan maka dilakukan beberapa tes, yaitu:

Pertama, uji Test Koefisien Penentu $\left(\mathrm{R}^{2}\right)$, pengetesan ini untuk mengetahui tepat tidaknya varibel yang mempengaruhi besarnya variabel yang diramalkan adalah waktu.

Kedua, Test Significance (T.Test) atau F test yaitu pengetesan untuk mengetahui apakah benar persamaan regresi itu adalah linier [3].

Tabel 1. Keeratan hubungan antara parameter (koefisien korelasi)

\begin{tabular}{|c|l|}
\hline Besar $\boldsymbol{r}_{\mathbf{y x}}$ & Keterangan \\
\hline $0,00-<0,20$ & $\begin{array}{l}\text { Hubungan sangat lemah } \\
\text { (diabaikan, dianggap tidak } \\
\text { ada) }\end{array}$ \\
\hline$\geq 0,20-<0,40$ & $\begin{array}{l}\text { Hubungan rendah atau } \\
\text { lemah }\end{array}$ \\
\hline$\geq 0,40-<0,70$ & $\begin{array}{l}\text { Hubungan sedang atau } \\
\text { cukup }\end{array}$ \\
\hline$\geq 0,70-<0,90$ & Hubungan kuat \\
\hline$\geq 0,90-<1,00$ & Hubunoan sanoat kuat \\
\hline
\end{tabular}




\section{METODE PENELITIAN}

\section{A. Studi Literatur}

Dalam studi literatur adalah melakukan pencarian informasi dan data yang penting mengenai segala sesuatu yang berhubungan dengan penelitian ini, diantaranya adalah:

1. Kebutuhan/permintaan energi listrik ialah besarnya energi listrik yang terpakai setiap tahun pada pelanggan PT. PLN (Persero) Wilayah Lampung.

2. Susut (losses) adalah suatu bentuk kehilangan energi listrik yang berasal dari selisih sejumlah energi listrik yang tersedia dengan sejumlah energi listrik yang terjual.

3. PDRB merupakan penjumlahan nilai output bersih perekonomian yang ditimbulkan oleh seluruh kegiatan ekonomi di suatu wilayah tertentu (provinsi dan kabupaten /Kota), dan dalam satu kurun waktu tertentu (satu tahun kelender). Kegiatan ekonomi yang dimaksud kegiatan pertanian, pertambangan, industri pengolahan, sampai dengan jasa.

4. Populasi penduduk, jumlah rumah tangga merupakan jumlah penduduk yang menempati/memadati suatu tempat atau daerah.

5. Prediksi adalah memperkirakan nilai populasi (parameter) dengan memakai nilai sampel (statistik tahun 2002-2013).

\section{B. Teknik Pengumpulan Data}

Pada tugas akhir ini data yang digunakan merupakan data sekunder yang diperoleh dari instansi pemerintah daerah, Badan Pusat Statistik Provinsi Lampung, Distamben Lampung, PT. PLN (Persero) Wilayah Lampung Sesuai dengan varaibel-variabel yang dibutuhkan yaitu jumlah pendapatan perkapita, jumlah penduduk, pdrb persektor, losses, rasio elektrifikasi, faktor beban, dan beban listrik yang terpasang dari tahun 2002 sampai tahun 2013.

\section{Perbandingan Antar Metode}

Untuk memastikan metode regresi linier adalah benar mendekati nilai aktual, maka dibuat perbandingan antara regresi linier sederhana, eksponesial smothing, dan rata-rata bergerak. Diambil contoh data aktual 5 tahun:

Tabel 2. Jumlah penduduk di Provinsi Lampung 20022006

\begin{tabular}{|c|c|}
\hline TAHUN & JUMLAH PENDUDUK \\
\hline 2002 & $6,787.65$ \\
\hline 2003 & $6,853.00$ \\
\hline 2004 & $6,915.95$ \\
\hline 2005 & $7,116.18$ \\
\hline 2006 & 721150 \\
\hline
\end{tabular}

Tabel 2 merupakan data sampel jumlah penduduk dari tahun 2002 sampai 2006 yang digunakan untuk melakukan perbandingan antar metode. Contoh perhintungan:

a) Metode Rata-rata bergerak

Metode rata - rata bergerak dapat dicari dengan menggunakan rumus:

$\mathrm{Y}=\frac{\sum(p d)}{n}$

Ket:

pd $\quad=$ Penjumlahan data

$\mathrm{N} \quad=$ Banyaknya data

Tabel 3. Data jumlah penduduk untuk metode rata-rata bergerak

\begin{tabular}{|c|c|}
\hline TAHUN & JUMLAH PENDUDUK \\
\hline 2002 & $6,787.65$ \\
\hline 2003 & $6,853.00$ \\
\hline 2004 & $6,915.95$ \\
\hline 2005 & $7,116.18$ \\
\hline 2006 & $7,211.59$ \\
\hline
\end{tabular}

Contoh perhitungan untuk tahun 2007:

$$
\begin{aligned}
\mathrm{Y} & =\frac{\sum(p n)}{n} \\
\mathrm{Y}_{2007}=\frac{\sum(p d)}{5} & \\
& =\frac{(34.884,37)}{5}
\end{aligned}
$$

$=\mathbf{6 . 9 7 6 , 8 7}$

b) Metode exponential smoothing

Tabel 4. Data jumlah penduduk untuk metode exponential smooting

\begin{tabular}{|c|c|}
\hline Tahun & JUMLAH PENDUDUK \\
\hline 2002 & $6.787,65$ \\
\hline 2003 & $6.853,00$ \\
\hline 2004 & $6.915,95$ \\
\hline 2005 & $7.116,18$ \\
\hline 2006 & $7.211,59$ \\
\hline
\end{tabular}

Asumsi:

Ke $1=0,2$

Ke $2=0,3$

Ke $3=0,5$

Contoh perhitungan untuk tahun 2007: 
$\mathrm{Y}=(6.915,95 \times 0,2)+(7.116,18 \times 0,3)+(7.211$ $59 \times 0,5)$

$\mathrm{Y}_{2007}=\mathbf{7 . 1 2 3 , 8 4}$

\section{c) Linier Sederhana}

Tabel 5. Data jumlah penduduk untuk metode regresi linier

\begin{tabular}{|c|c|}
\hline Tahun & JUMLAH PENDUDUK \\
\hline 2002 & $6.787,65$ \\
\hline 2003 & $6.853,00$ \\
\hline 2004 & $6.915,95$ \\
\hline 2005 & $7.116,18$ \\
\hline 2006 & $7.211,59$ \\
\hline
\end{tabular}

$\mathrm{b}=\frac{\sum x y-n \bar{x} \bar{y}}{\sum x^{2}-n \bar{x}^{2}}$

$\mathrm{a}=\bar{y}-\mathrm{b} \bar{x}$

$\mathrm{b}=\frac{(492718,39)-(11 \times 6 \times 7.290,77)}{(506)-\left(11 \times\left(6^{2}\right)\right)}$

$=104,80$

$\mathrm{a}=(7.290,77)-(104,80 \times 12)$

$\mathrm{Y}_{2007}=\mathbf{7 . 3 1 0 , 1 9}$

Setelah dilakukan perbandingan antar metode didapatkan hasil sebagai berikut:

Tabel 6. Perbandingan hasil hitung metode

\begin{tabular}{|l|l|l|l|l|}
\hline Tahun & $\begin{array}{l}\text { Data } \\
\text { Aktual }\end{array}$ & $\begin{array}{l}\text { Rata-rata } \\
\text { Bergerak }\end{array}$ & $\begin{array}{l}\text { Expontial } \\
\text { Smoothing }\end{array}$ & $\begin{array}{l}\text { Linier } \\
\text { Sederhana }\end{array}$ \\
\hline 2007 & $\mathbf{7 . 2 8 9 , 7 7}$ & $7.081,24$ & $7.123,84$ & $7.310,19$ \\
\hline 2008 & $7.391,13$ & $7.205,85$ & $7.231,60$ & $7.421,30$ \\
\hline 2009 & $7.526,45$ & $7.297,50$ & $7.324,81$ & $7.532,40$ \\
\hline 2010 & $7.608,41$ & $7.402,45$ & $7.438,52$ & $7.643,51$ \\
\hline 2011 & $7.691,01$ & $7.508,66$ & $7.540,37$ & $7.754,62$ \\
\hline 2012 & $\mathbf{7 , 8 0 7 . 3 0}$ & 7608.623 & 7633.318 & $7,865.72$ \\
\hline
\end{tabular}

Setelah dilakukan perbandingan antar metode, diambil kesimpulan bahwa metode regresi linier lebih akurat dibandingkan metode yang lain, dapat dilihat dari hasil estimsi berbagai metode, metode regresi linier paling mendekati nilai aktual.

\section{Metode Prediksi Dengan Regresi Linier}

Setelah menguji beberapa metode pada penelitian ini, akhirnya digunakan metode regresi linier, regresi linier dalam penelitian ini dibagi menjadi dua, yaitu:

a) Regresi Linier Sederhana

$\mathbf{Y}=\mathbf{A}+\mathbf{B X}$ b) Regresi Linier Berganda

$Y_{t}=\mathbf{a}+B_{1} \cdot X_{1 t}+B_{2} \cdot X_{2 t}$ $+B_{n} \cdot X_{n t}$

Penggunaan metode ini didasarkan kepada variabel yang ada dan yang akan mempengaruhi hasil prediksi.

Hal-hal yang perlu diketahui sebelum melakukan prediksi dengan metode regresi adalah mengetahui terlebih dahulu mengetahui kondisi- kondisi seperti:

a. Adanya informasi masa lalu

b. Informasi yang ada dapat dibuatkan dalam bentuk data (dikuantifikasikan)

c. Diasumsikan bahwa pola data yang ada dari data masa lalu akan berkelanjutan dimasa yang akan datang.

\section{Regresi Linier Sederhana}

Bentuk hubungan yang paling sederhana antara variabel Xdengan variabel Yadalah berbentukgarislurusatau berbentukhubunganlinieryang

disebutdenganregresilinier sederhanaatau sering disebut regresi linier dengan persamaan 1sebagaiberikut:

$\mathrm{Y}=\mathrm{A}+\mathrm{BX}$

ApabilaAdanBmengambilnilaiseperti: $A=0$ dan $B=1$ Daripersamaan

diatas,AdanBdisebutkonstantaataukoefisienregresi liniersederhanaatauparametergarisregresiliniersede rhana.A disebutintercept coefficient atauintersep yaitujaraktitikasalatautitikacuandengan titikpotonggaris regresidengansumbuY;danBdisebutslopecoefficien $\boldsymbol{t}$ atauslupyangmenyatakan ataumenunjukkankemiringanataukecondongan garisregresiterhadapsumbuX. Dari persamaan garisregresi (1),dalamhubungan tersebutterdapat satuvariabel bebasXdansatuvariabeltakbebas Y.

Analisis regresi linier sederhana digunakan untuk memprediksi jumlah penduduk, rasio elektrifikasi,

faktor beban, losses, jumlah rumah tangga dan pdrb konstan pada tahun 20013 sampai 2030.

Pertama mencari nilai $b$ dan dapat dicari dengan rumus: $b=\frac{\sum x y-n \overline{x y}}{\sum x^{2}-n \bar{x}^{2}}$

Kemudian mencari nilai a dengan rumus: $\mathbf{a}=\overline{\boldsymbol{y}}-\mathbf{b} \overline{\boldsymbol{x}}$

Dan mendapatkan hasil Y dengan rumus: $\mathbf{Y}=\mathbf{a}+\mathbf{b} \mathbf{x}$

\section{Regresi Linier Berganda}

Modelregresilinieriniberhubungan secara linear antara dua atau lebih variabel independen $\left(X_{1}, X_{2}\right.$, . $\mathrm{X}_{\mathrm{n}}$ ) dengan variabel dependen $(\mathrm{Y})$. 
$Y_{t}=a+B_{1} \cdot X_{1 t}+B_{2} \cdot X_{2 t}$ $+\mathbf{B}_{\mathrm{n}} \cdot \mathbf{X}_{\mathrm{nt}}$

Analisis regresi linier berganda digunakan untuk memprediksi jumlah daya terpasang (rumah tangga, publik, industri, bisnis) sebagai (Y) di Provinsi Lampung pada tahun 2014 sampai 2030 ditinjau dari dan (pdrb, losses, faktor beban, jumlah penduduk, jumlah rumah tangga, dan rasio elektrifikasi) Sebagai (X) yang telah diprediksi menggunakan analisis regresi linier sederhana.

Untuk mecari nilai konstanta dan variable regresi setiap variabel bebas dapat diperoleh dengan menggunakan matriks determinan [4]:

$\mathrm{A}=$

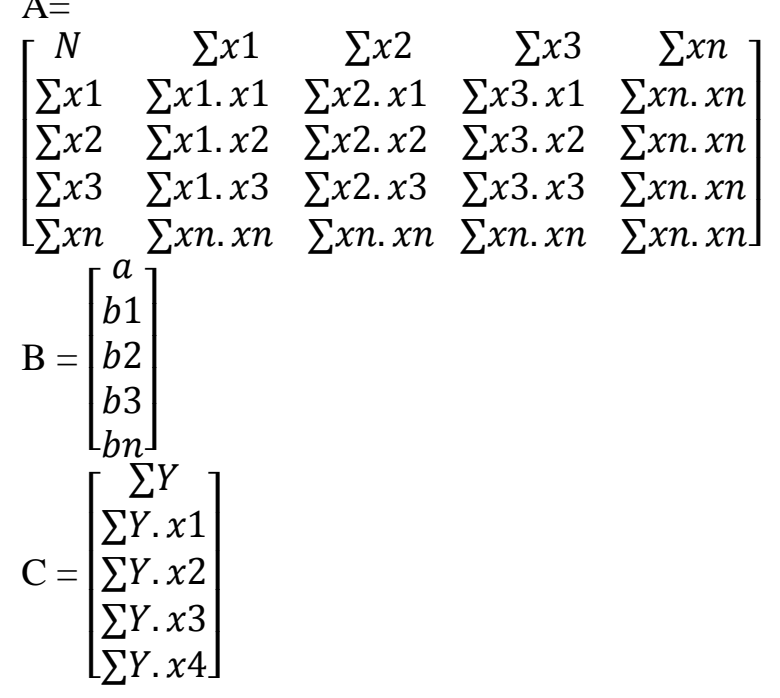

Kemudian dapat diperoleh nilai a, b1, b2, b3 sebagai berikut:

$$
\begin{aligned}
a & =\frac{\operatorname{Det}(A 0)}{\operatorname{Det} A} \\
b 1 & =\frac{\operatorname{Det}(A 1)}{\operatorname{Det} A} \\
b 2 & =\frac{\operatorname{Det}(A 2)}{\operatorname{Det} A} \\
b 3 & =\frac{\operatorname{Det}(A 3)}{\operatorname{Det} A} \\
b n & =\frac{\operatorname{Det}(A n)}{\operatorname{Det} A}
\end{aligned}
$$

$Y_{t}=a+B_{1} \cdot X_{1 t}+B_{2} \cdot X_{2 t}+B_{3} \cdot X_{3 t}$ $+\mathbf{B}_{\mathrm{n}} \cdot \mathbf{X}_{\mathrm{nt}}$

$\mathrm{Y}_{\mathrm{t}}=$ Hasil Prediksi

$\mathrm{a}=$ Konstanta

$\mathrm{X}_{1}=$ Variabel bebas 1

$\mathrm{X}_{2}=$ Variabel bebas 2

$\mathrm{X}_{3}=$ Variabel bebas 3

$\mathrm{X}_{\mathrm{n}}=$ Variabel bebas $\mathrm{n}$

\section{E. Diagram Alur Penelitian}

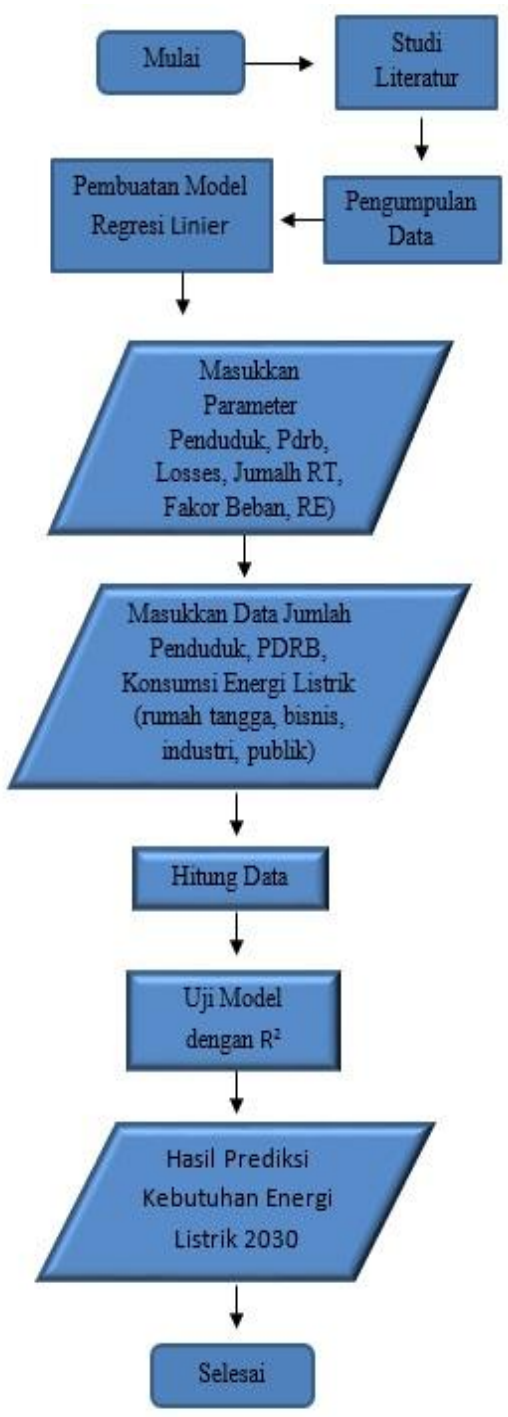

Gbr 1. Diagram Alir Penelitian

\section{HASIL DAN PEMBAHASAN}

\section{A. Model yang dibangun dalam melakukan prediksi}

Dalam melakukan prediksi kebutuhan energi listrik jangka panjangdi Provinsi Lampung maka dibangunlah macam-macam model regresi linier dengan memvariasikan parameternya, untuk model konsumsi energi listrik (Electricity Consumption) menggunakan parameter : jumlahpenduduk (x1), PDRB (x2), jumlah Pelanggan Listrik (x3), faktor beban (x4), losses (x5), dan penjualan listrik (x6). Dan untuk model daya tersambung (Connected Load) menggunakan parameter : jumlah penduduk (x1), PDRB (x2), Rasio Elektrifikasi (x3), faktor beban (x4), losses (x5), jumlah rumah tangga (x6). 


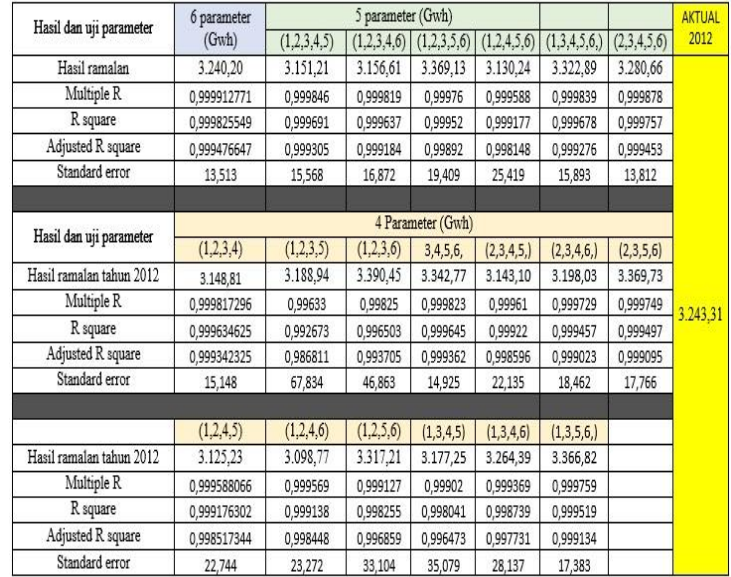

Gbr 2. Hasil uji model konsumsi listrik

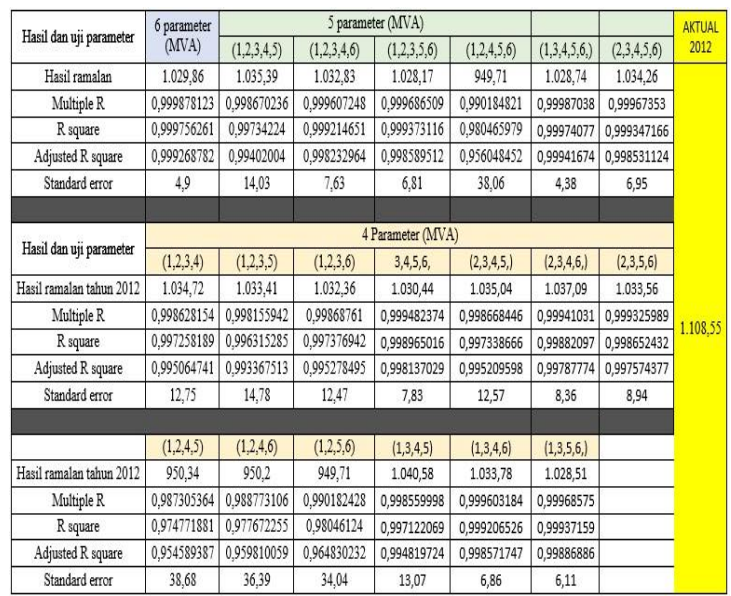

Gbr 3. Hasil uji daya tersambung

Setelah dilakukan percobaan memvariasikan beberapa model, untuk model daya tersambung didapatkan kesimpulan memilih 6 parameter dikarenakan standard error nya sangat kecil dan R2 lebih besar dibandingkan model 4, dan 5 paramter yang lain. Hal tersebut dikarenakan parameter yang digunakan sangat berkaitan (korelasi), dan untuk model konsumsi energi listrik juga memilih 6 parameter dikarenakan errornya lebih kecil dan mendekati nilai aktual, Sehingga untuk persamaan 6 paramter, sebagai berikut :

$Y_{t}=a+B_{1} \cdot X_{1 t}+B_{2} \cdot X_{2 t}+B 3 \cdot X_{3 t}+B_{4} \cdot X_{4 t}+B_{5} \cdot X_{5 t}$ $+\mathbf{B}_{6} \cdot \mathbf{X}_{6 \mathrm{t}}$

Model matematis diatas merupakan metode regresi linier berganda yang digunakan untuk melakukan prediksi kebutuhan energi listrik jangka panjang di Provinsi Lampung hingga 2030.

Setelah dilakukan pengujian model, didapatkan bahwa faktor yang mempengaruhi kebutuhan energi listrik di Provinsi Lampung dibagi menjadi 2 parameter, yaitu: parameter ekonomi, dan parameter listrik. Dari sisi ekonomi, hal-hal yang mempengaruhi kebutuhan energi listrik yaitu: Produk domestic regional bruto (PDRB), jumlah penduduk, dan jumlah rumah tangga. Sedangkan dari sisi listrik, yaitu: rasio elektrifikasi, faktor beban, dan $d$-losses.

\section{B. Hasil Prediksi Daya Listrik Tersambung di Provinsi Lampung}

Berkaitan dengan energi yang terpakai sangat berkaitan dengan pelanggan. Pelanggan listrik yang ada di PT. PLN wilayah Lampung dibedakan berdasarkan jenis tarifnya ada 4 jenis tarif yaitu: pelanggan rumah tangga (tarif $\mathrm{R}$ ), pelanggan publik (tarif S), pelanggan bisnis (tarif B) dan pelanggan industri (tarif I), penggolongan tarif tersebut berdasarkan batas daya tersambung.

a). Prediksi daya tersambung sektor rumah tangga Hasil prediksi daya listrik tersambung sektor rumah tangga tahun 2014-2030, sebagai berikut:

Tabel 7. Hasil prediksi daya listrik tersambung sektor rumah tangga

\begin{tabular}{|c|c|}
\hline Tahun & $\begin{array}{c}\text { Prediksi Daya Listrik } \\
\text { Tersambung Rumah Tangga } \\
\text { (MVA) }\end{array}$ \\
\hline 2014 & $1.399,06$ \\
\hline 2015 & $1.472,56$ \\
\hline 2016 & $1.546,06$ \\
\hline 2017 & $1.619,56$ \\
\hline 2018 & $1.693,06$ \\
\hline 2019 & $1.766,56$ \\
\hline 2020 & $1.822,28$ \\
\hline 2021 & $1.848,79$ \\
\hline 2022 & $1.875,30$ \\
\hline 2023 & $1.901,81$ \\
\hline 2024 & $1.928,32$ \\
\hline 2025 & $1.954,82$ \\
\hline 2026 & $1.981,33$ \\
\hline 2027 & $2.007,84$ \\
\hline 2028 & $2.034,35$ \\
\hline 2029 & $2.060,86$ \\
\hline 2030 & $2.087,37$ \\
\hline
\end{tabular}

Grafik hasil prediksi jumlah daya listrik tersambung untuk sektor rumah tangga dari tahun 2014 sampai 2030 dapat digambarkan seperti pada kurva linier di bawah ini :

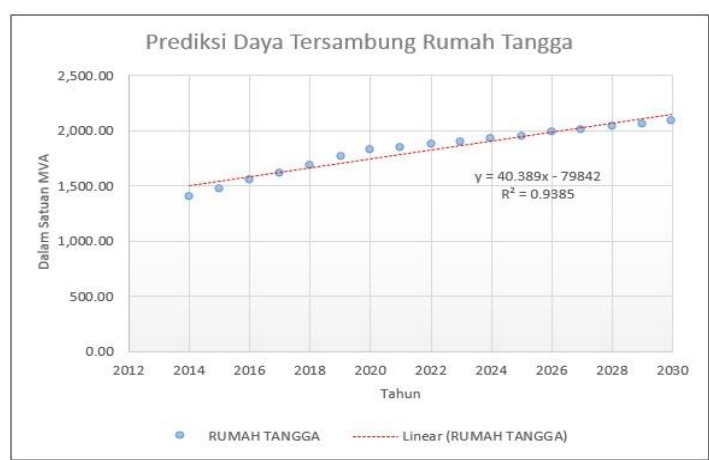

Gbr 4. Hasil prediksi sektor rumah tangga 2014-2030 
Dari gambar 4 yaitu grafik pertumbuhan jumlah daya listrik tersambung sektor rumah tangga, Dapat dilihat hasil prediksi rumah tangga di Provinsi Lampung, pada tahun 2014 sebesar 1.399,06 MVA, dan rata-rata kenaikannya sebesar 2,46\%, Pada tahun 2030 daya tersambung sektor rumah tangga di Provinsi Lampung sebesar 2.087,37 MVA.

\section{b). Prediksi daya tersambung sektor bisnis}

Hasil prediksi kebutuhan energi listrik sektor bisnis tahun 2014-2030, sebagai berikut:

Tabel 8. Hasil Prediksi Daya Listrik Tersambung Sektor Bisnis

\begin{tabular}{|c|c|}
\hline Tahun & $\begin{array}{c}\text { Prediksi Daya Listrik } \\
\text { Tersambung Bisnis (MVA) }\end{array}$ \\
\hline 2014 & 237,43 \\
\hline 2015 & 248,33 \\
\hline 2016 & 259,23 \\
\hline 2017 & 270,13 \\
\hline 2018 & 281,03 \\
\hline 2019 & 291,93 \\
\hline 2020 & 302,53 \\
\hline 2021 & 312,65 \\
\hline 2022 & 322,78 \\
\hline 2023 & 332,90 \\
\hline 2024 & 343,02 \\
\hline 2025 & 353,14 \\
\hline 2026 & 363,26 \\
\hline 2027 & 373,38 \\
\hline 2028 & 383,50 \\
\hline 2029 & 393,62 \\
\hline 2030 & 403,74 \\
\hline
\end{tabular}

Grafik prediksi jumlah daya listrik tersambung sektor bisnis dari tahun 2014 sampai 2030dapat digambarkan padakurva dibawah ini :

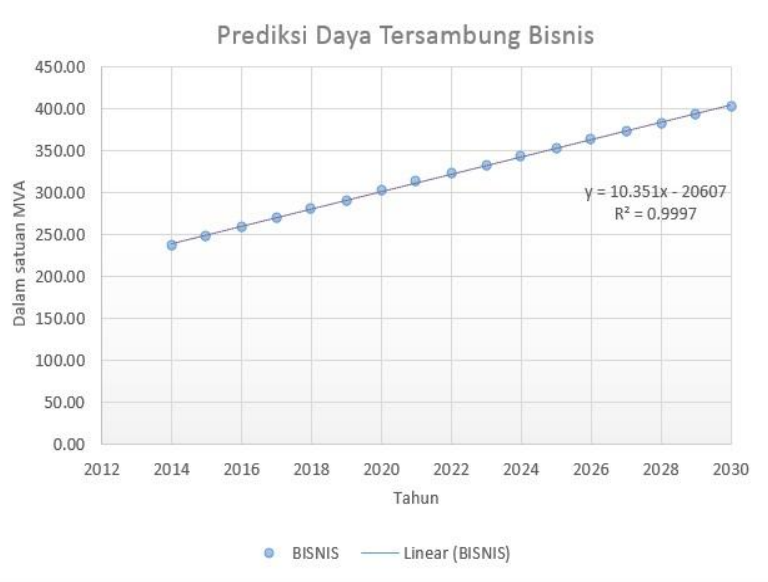

Gbr 5. Hasil prediksi sektor bisnis 2014-2030.
Dari gambar 5 yaitu grafik pertumbuhan jumlah daya listrik tersambung di Provinsi Lampung sektor bisnis. Dapat dilihat hasil prediksi untuk sektor bisnis pada tahun 2014 sebesar 237,43 MVA, dan rata-rata kenaikannya sebesar 3, $26 \%$, Pada tahun 2030 jumlah daya tersambung sektor bisnis di Provinsi Lampung sebesar 403,74 MVA.

\section{c). Prediksi daya tersambung sektor public}

Hasil prediksi kebutuhan energi listrik sektor publik tahun 2014-2030, sebagai berikut:

Tabel 9. Hasil Prediksi Daya Listrik Tersambung Sektor publik

\begin{tabular}{|c|c|}
\hline Tahun & $\begin{array}{c}\text { Prediksi Daya Listrik } \\
\text { Tersambung Publik (MVA) }\end{array}$ \\
\hline 2014 & 116,62 \\
\hline 2015 & 123,28 \\
\hline 2016 & 129,94 \\
\hline 2017 & 136,60 \\
\hline 2018 & 143,26 \\
\hline 2019 & 149,91 \\
\hline 2020 & 156,02 \\
\hline 2021 & 161,20 \\
\hline 2022 & 166,38 \\
\hline 2023 & 171,57 \\
\hline 2024 & 176,75 \\
\hline 2025 & 181,94 \\
\hline 2026 & 187,12 \\
\hline 2027 & 192,31 \\
\hline 2028 & 197,49 \\
\hline 2029 & 202,68 \\
\hline 2030 & 207,86 \\
\hline
\end{tabular}

Grafik prediksi jumlah daya listrik tersambung sektor publik dari tahun 2014 sampai 2030 dapat digambarkan pada kurva di bawah ini :

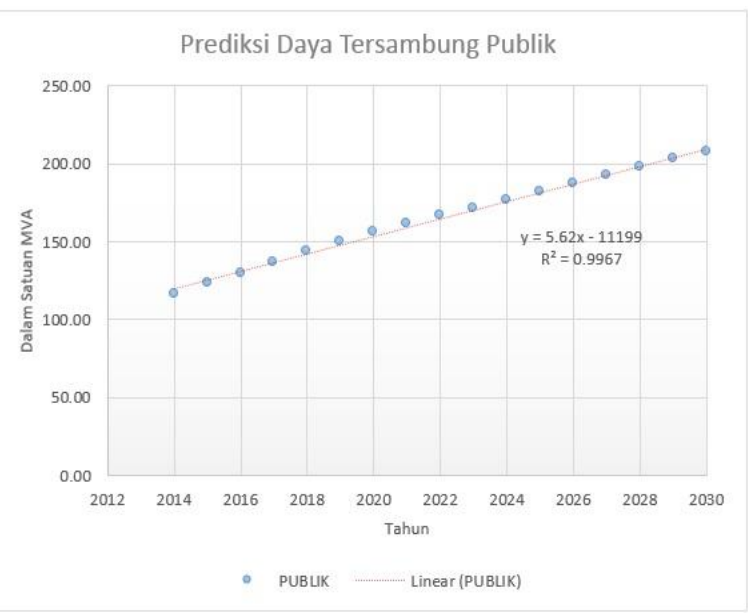

Gbr 6. Hasil prediksi sektor publik 2014-2030. 
Dari gambar 6 yaitu grafik pertumbuhan jumlah daya listrik tersambung di Provinsi Lampung untuk sektor publik, Dapat dilihat hasil prediksi untuk sektor publik pada tahun 2014 sebesar 116,62 MVA, dan rata-rata kenaikannya sebesar 3, $54 \%$, Pada tahun 2030 jumlah daya tersambung sektor publik di Provinsi Lampung sebesar 207,86 MVA.

\section{d). Prediksi daya tersambung sektor industri}

Hasil prediksi daya listrik tersambung sektor industri tahun 2014-2030:

Tabel 10. Hasil prediksi Sektor Industri

\begin{tabular}{|c|c|}
\hline Tahun & $\begin{array}{c}\text { Prediksi Daya Listrik } \\
\text { Tersambung Industri (MVA) }\end{array}$ \\
\hline 2014 & 347,64 \\
\hline 2015 & 366,82 \\
\hline 2016 & 386,00 \\
\hline 2017 & 405,19 \\
\hline 2018 & 424,37 \\
\hline 2019 & 443,55 \\
\hline 2020 & 453,24 \\
\hline 2021 & 447,33 \\
\hline 2022 & 441,42 \\
\hline 2023 & 435,50 \\
\hline 2024 & 429,59 \\
\hline 2025 & 423,68 \\
\hline 2026 & 417,77 \\
\hline 2027 & 411,85 \\
\hline 2028 & 405,94 \\
\hline 2029 & 400,03 \\
\hline 2030 & 394,11 \\
\hline
\end{tabular}

Grafik prediksi jumlah daya listrik tersambung untuk pelanggan publik dari tahun 2014 sampai 2030 dapat digambarkan seperti pada kurva di bawah ini :

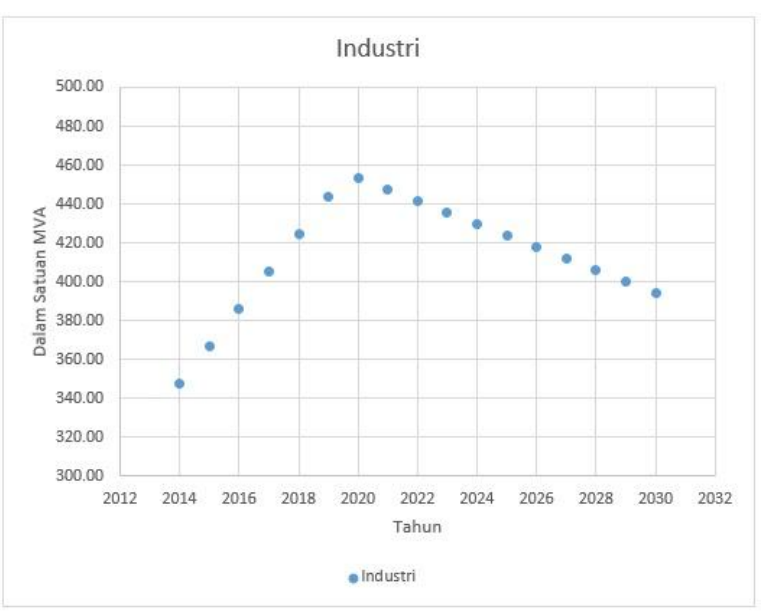

Gbr 7. Hasil prediksi sektor industri 2014-2030.

Dari gambar 7 yaitu grafik pertumbuhan jumlah daya listrik tersambung di Provinsi Lampung untuk sektor industri, Dapat dilihat hasil prediksi untuk sektor pada tahun 2014 sebesar 347,64 MVA, dan rata-rata kenaikannya sebesar $0,74 \%$, Pada tahun 2030 jumlah daya tersambung sektor industri di Provinsi Lampung sebesar 394,11 MVA.

\section{Hasil Prediksi Konsumsi Energi Listrik}

Hasil prediksi konsumsi energi listrik di Provinsi Lampung tahun 2014-2030:

Tabel 11. Hasil prediksi konsumsi energi Listrik

\begin{tabular}{|c|c|}
\hline Tahun & $\begin{array}{c}\text { Prediksi Konsumsi Energi } \\
\text { Listrik (Gwh) }\end{array}$ \\
\hline 2014 & $3.986,87$ \\
\hline 2015 & $4.203,32$ \\
\hline 2016 & $4.419,78$ \\
\hline 2017 & $4.636,24$ \\
\hline 2018 & $4.852,69$ \\
\hline 2019 & $5.069,15$ \\
\hline 2020 & $5.285,61$ \\
\hline 2021 & $5.502,06$ \\
\hline 2022 & $5.718,52$ \\
\hline 2023 & $5.934,98$ \\
\hline 2024 & $6.151,43$ \\
\hline 2025 & $6.367,89$ \\
\hline 2026 & $6.584,35$ \\
\hline 2027 & $6.800,80$ \\
\hline 2028 & $7.017,26$ \\
\hline 2029 & $7.233,72$ \\
\hline 2030 & $7.450,17$ \\
\hline
\end{tabular}

Tabel diatas merupakan hasil prediksi konsumsi energi listrik di Provinsi Lampung tahun 20132030. Dapat dilihat setiap tahun konsumsi listrik terus meningkat, rata-rata kenaikan konsumsi listrik sebesar 4, 05\%. Hal ini dikarenakan jumlah penduduk terus bertambah sehingga kebutuhan listrik semakin menigkat.

Grafik hasil prediksi konsumsi energi listrik tahun 2014-2030 dapat dilihat dibawah ini:

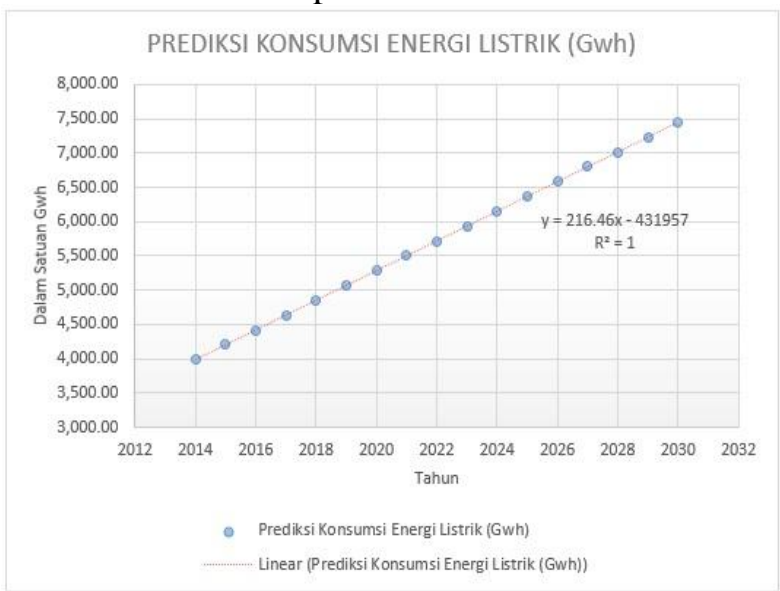

Gbr 8. Hasil prediksi konsumsi energi listrik2014-2030. 
Dari gambar diatas yaitu grafik pertumbuhan jumlah konsumsi listrik di Provinsi Lampung. Dapat dilihat pada tahun 2014 hasil prediksi konsumsi listrik di Provinsi Lampung, sebesar 3.986,87 Gwh, dan rata-rata kenaikannya sebesar 3,83\%, Pada tahun 2030 jumlah daya tersambung sektor bisnis di Provinsi Lampung sebesar 7.450,17 Gwh.

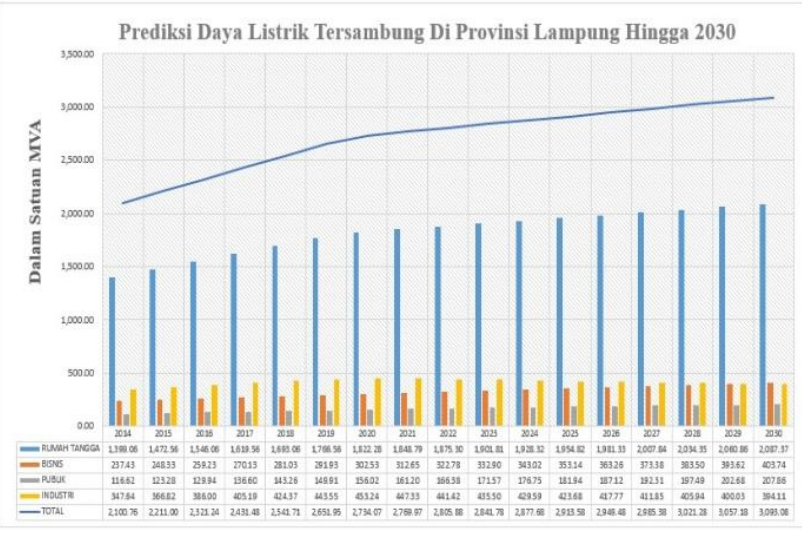

Gbr 9. Total hasil prediksi daya listrik tersambung hingga 2030

\section{Analisa dan Pembahasan}

Dari hasil prediksi kebutuhan energi listrik yang telah dilakukan dari tahun 2014 sampai dengan tahun 2030 terlihat bahwa setiap tahunnya kebutuhan energi listrik di Provinsi Lampung terus meningkat. Hasil prediksi regresi diperoleh bahwa jumlah daya listrik tersambung untuk pelanggan rumah tangga, bisnis, industri dan publik terlihat bahwa setiap tahunnya mengalami peningkatan, berdasarkan gambar 9, yaitu kurva regresi jumlah daya listrik tersambung menunjukkan bahwa terjadi peningkatan yang linier. Dari hasil prediksi daya listrik tersambung untuk pelanggan Rumah tangga pada tahun 2014 diperoleh bahwa daya listrik tersambung sebesar 1.399,06 MVA, pada tahun 2028 meningkat menjadi 2.034,35 MVA, meningkat sebesar $31,23 \%$ (rata-rata pertumbuhannya sebesar 2,46\%) dan ini sesuai dengan gambar 4, yaitu suatu kurva yang menunjukkan bahwa terjadi peningkatan yang linier. Dan untuk konsumsi energi listrik di Provinsi Lampung setiap tahunnya mengalami peningkatan yang tidak terlalu signifikan dibandingkan tahun 2013, pada tahun 2014 hasil prediksi konsumsi energi listrik di Provinsi Lampung sebesar 3.986,87 Gwh, pada tahun 2023 prediksi konsumsi energi listrik meningkat mejadi 5.934,98 Gwh, atau menigkat sebesar 26,50\% (rata-rata peningkatan konsumsi energi listrik di Provinsi Lampung sebesar 3,83\%) dan ini sesuai dengan gambar 8, yaitu suatu kurva yang menunjukkan bahwa terjadi peningkatan yang sangat linier.

\section{KESIMPULAN}

Berdasarkan pembahasan hasil penelitian, maka dapat ditarik suatu kesimpulan yaitu : hasil prediksi daya listrik tersambung untuk pelanggan rumah tangga pada tahun 2014 diperoleh bahwa daya listrik tersambung sebesar 1.399,06 MVA, pada 2028 meningkat menjadi 2.034,35 MVA, meningkat sebesar $31,23 \%$ (rata-rata pertumbuhannya sebesar 2,46\%).Konsumsi energi listrik di Provinsi Lampung setiap tahunnya mengalami peningkatan yang tidak terlalu signifikan dibandingkan tahun 2013, pada tahun 2014 hasil prediksi konsumsi energi listrik di Provinsi Lampung sebesar 3.986,87 Gwh, pada tahun 2023 prediksi konsumsi energi listrik meningkat mejadi 5.934,98 Gwh, atau menigkat sebesar 26,50\% (rata-rata peningkatan konsumsi energi listrik di Provinsi Lampung sebesar 3,83\%)

\section{REFERENSI}

[1] A. Nugroho, "Prediksi Kebutuhan Energi Listrik UPJ Boja," Teknik Elektro UNDIP, Semarang, 2005.

[2] D. Suswanto, "Analisis Prediksi Beban dan Kebutuhan Energi LIstrik," in Sistem Distribusi Tenaga Listrik, 2010, p. 201.

[3] V. Gaspers, production planning and inventory control, Jakarta: PT Gramedia , 1998.

[4] S. Solima, Electrical Load Predictioning, United States: Elsevier Inc., 2010.

[5] T. Gonen, Electric Power Distribution System, New York: McGraw Hili Book Company, 1986.

[6] D. Marsudi, Pembangkit Energi Elektrik, Jakarta: Erlangga, 2005.

[7] M. Jenifer, "Binus.ac.id," 2007. [Online]. Available:

http://thesis.binus.ac.id/doc/Bab3/2007-2-

00592-TISI-Bab\%203.pdf. [Accessed 10 Desember 2013].

[8] M. N. Hesham K.A, "Electri Load Predictioning," Literature Survey and Classication Of Methods, vol. 33, pp. 23234.

[9] Makridakis S. and S.C. Wheelwright, Predictioning Methods," 1989. 